\title{
Bio Activity of Sesbania Grandiflora against Hepatic Damage in Albino Rats
}

\author{
Article by K. Padmalochana ${ }^{1}$ and M.S. Dhana Rajan ${ }^{2}$ \\ ${ }^{1}$ Research Scholar, Bharathiar University, Coimbatore, Tamil Nadu, India \\ ${ }^{2}$ Registrar, Texila American University, Guyana, South America \\ E-mail: kpadmalochana@gmail.com ${ }^{1}$
}

\begin{abstract}
A phytotherapeutic approach to modern drug development can provide many invaluable drugs from traditional medicinal plants. Medicinal plants have been considered as important therapeutic aid for alleviating ailment of humankind. Numerous plants and polyherbal formulations are used for the treatment of liver diseases. This present investigation was aimed to assessing the hepatoprotective activity of aqueous, ethanol and acetone extract of Sesbania grandiflora leaves against carbon tetra chloride $\left(\mathrm{CCl}_{4}\right)$ induced liver damage in albino rats. Silymarin as standard drug for comparing the activity. The activity was assessed by comparing the biochemical parameters in serum levels such as serum glutamate pyruvate transaminase, serum glutamate oxalate transaminase, total bilirubin, alkaline phosphatase of plant extracts treated group with carbon tetrachloride treated animals. Results showed, ethanolic extract treated group showed highly significant activity $(p<0.001)$, whereas aqueous extract treated group has shown the significant $(p<0.01)$ action but less compared with ethanolic extract, acetone treated group showed moderate action. Plant extracts restores biochemical enzymes and brings down to normal as compared to standard drug silymarin. This results shows and confirms the significant protective activity against CCl induced hepatotoxicity.
\end{abstract}

Keywords: Phytotherapeutic, Sesbania Grandiflora, Antioxidant, Carbon Tetra Chloride, Hepatotoxicity.

\section{Introduction}

Liver is very important organ in the human body. It regulates metabolic functions such as detoxification and play vital role in bio-chemical conversion. During the process of elimination there is chance of accumulation different kinds of toxic materials inside the hepatocytes and there is chance of liver infection, and hepatic disorders such as hepatitis ". Liver diseases caused by various toxic chemicals, chemotherapeutic agents, excessive consumption of alcohol and microorganisms. Hepatotoxicity is an acute adverse effect in liver in caused by over dosages of drugs, toxic chemicals, viruses, bacteria and parasites $^{2}$.

Hepatotoxicity is a slight changes in hepatic structure and function which may result hypertension, ascites, jaundice, increased bleeding and cause multiple metabolic changes affecting other organs ${ }^{3,4}$. The magnitude of derangement of liver by disease or hepatotoxin is generally measured by the level of glutamate pyruvate transaminase (ALT), glutamate oxaloacetate transaminase (AST), alkaline phosphatase (ALP), bilirubin, albumin, and whole liver homogenate ${ }^{4,5}$.

$\mathrm{CCl}_{4}$ is a widely used industrial chemical and a potent hepatotoxin. It induces hepatotoxicity by producing free radical, putting oxidative stress hence causing lipid peroxidation in liver tissues, consequently necrotic liver damage ${ }^{6,7}$. Liver diseases such as hepatitis, cirrhosis and fatty liver are worldwide. Various commercial synthetic drugs are used to treat liver disorders also cause side effect to the liver. Hence, Herbal drugs have become increasingly popular and their use is widespread. Herbal medicines have been used in the treatment of liver diseases for a long time. In India numerous medicinal plants are used for treatment of liver disorders ${ }^{8}$. Hepatoprotective effect of some plants like Spirulina maxima ${ }^{9}$ Eclipta alba ${ }^{10}$, Boehmerianivea ${ }^{11}$, Cichorium intybus ${ }^{12}$, and Picrorhiza kurroa ${ }^{13}$, Boswellia Serrata ${ }^{4}$, Psidium quajava ${ }^{14}$, Coccinia indica ${ }^{15}$ has been well documented. 
DOI: $10.21522 /$ TIJBMS.2016.02.02.Art001

ISSN: $2519-500 \mathrm{X}$

Sesbania grandifloraa Figure. 1 fast growing tree belongs to the family, Fabaceae, is commonly known as agathi in regional language Tamil. The leaves, used as greens for cattle and poultry, have got anthelmintic property against selected helminthes ${ }^{16,17}$. The bark, leaves, flowers and roots are also used medically herbs distributed in the tropical regions of the globe ${ }^{18}$. Juice of leaves and flowers is popular remedy for nasal catarrh and headache when it is sniffed up the nostrils. Juice of the flowers is squeezed into the eyes to relieve the dimness of vision.

Juice of flower is ideal as expectorant ${ }^{19}$. The leaves of the plant have been reported to have anxiolytic and anticonvulsant effect while the flowers have been reported to have anti-microbial activity ${ }^{20}$. It shows hypolipemic, anti-ulcer and anti-inflammatory properties as well. Therefore, to justify the traditional claims, we have assessed the hepatoprotective effect of Sesbania grandiflora leaves extract in albino rats using biochemical enzyme based analysis.

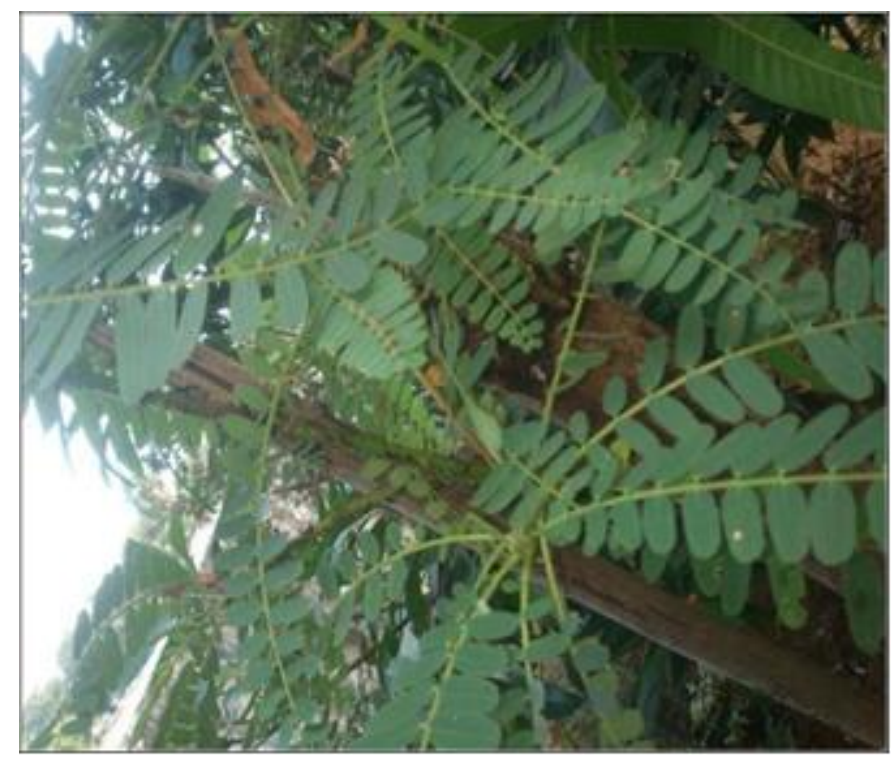

Figure 1. Sesbania grandiflora leaves

\section{Materials and methods}

Chemicals: Analytical grade carbon tetra chloride, Silymarin and other chemicals were purchased from Himedia laboratories private limited, Mumbai. Sesbania grandiflora plant was collected from, Tiruvannamalai, South India.

\section{Preparation of plant extracts}

Sesbania grandiflora leaves were collected and shade dried at room temperature. The shade dried leaves were powdered and extracted by using aqueous, ethanol and acetone. Aqueous extracts was prepared by subjecting a $100 \mathrm{~g}$ of dried powdered leaves in to $100 \mathrm{ml}$ of distilled water and incubated in water bath shaker for $12 \mathrm{~h}$ at $40^{\circ} \mathrm{C}$. Ethanol and acetone extract prepared by the coarsely powdered leaves was extracted using soxhlet and extracted with $80 \%$ ethanol and $70 \%$ acetone for $24 \mathrm{~h}$ at $60{ }^{\circ} \mathrm{C}$ and $55^{\circ} \mathrm{C}$, respectively. The extracted were collected and concentrated by drying under vaccum and semisolid suspensions were obtained. These suspensions were used to assess hepatoprotective activity.

\section{Experimental design for hepatoprotective activity of sesbania grandiflora}

Adult male Wister albino rats maintained at the college weighing between $150 \mathrm{~g}-170 \mathrm{~g}$ were used for the hepatoprotective studies. Animals were divided into six groups in six rats each:

Group I (Normal): Orally received distilled water for 7 days.

Group II (Induced): Orally received carbon tetra chloride ( $2 \mathrm{~g} / \mathrm{kg}$ body weight) only for 7 days. 
Group III (Standard): Orally received Silymarin ( $20 \mathrm{mg} / \mathrm{kg}$ body weight) along with $\mathrm{CCl}_{4}(2 \mathrm{~g} / \mathrm{kg}$ body weight) for 7 days.

Group IV (Treatment): Orally received Aqueous leaf extracts $(300 \mathrm{mg} / \mathrm{kg}$ body weight) along with $\mathrm{CCl}_{4}(2 \mathrm{~g} / \mathrm{kg}$ body weight) for 7 days.

Group V (Treatment): Orally received ethanol leaf extracts $\left(300 \mathrm{mg} / \mathrm{kg}\right.$ body weight) along with $\mathrm{CCl}_{4}$ $(2 \mathrm{~g} / \mathrm{kg} / \mathrm{body}$ weight $)$ for 7 days.

Group VI (Treatment): Orally received acetone leaf extracts (300 $\mathrm{mg} / \mathrm{kg}$ body weight) along with $\mathrm{CCl}_{4}$ $(2 \mathrm{~g} / \mathrm{kg}$ body weight $)$ for 7 days.

Silymarin was used as positive control for comparing hepatoprotective potential of different leaves extract of Sesbania grandiflora.

\section{Hepatoprotective activity of S. grandiflora}

\section{Collection of blood and biochemical analysis}

On the $8^{\text {th }}$ day, all the animals were scarified and blood samples were collected in glass tube from retroorbital puncture to obtain haemolysis for $30 \mathrm{~min}$ at $37^{\circ} \mathrm{C}$. Serum glutamate oxaloacetate transaminase, serum glutamate pyruvate transaminase, serum bilirubin and alkaline phosphatase and Serum protein ${ }^{21,22}$ were obtained from serum following centrifugation process was used for the biochemical analysis.

\section{Antioxidant activity of S. grandiflora}

\section{Liver homogenate preparation}

Liver homogenates were prepared by using a $100 \mathrm{mM} \mathrm{KCl}$ buffer $(\mathrm{pH} 7.0)$ containing $0.3 \mathrm{mM}$ EDTA and centrifuged at $6000 \mathrm{rpm}$ for $45 \mathrm{~min}$ at $4{ }^{\circ} \mathrm{C}$. After completion of centrifugation process collect the supernatant was used for estimation of antioxidant levels were analyzed Superoxide dismutase (SOD) ${ }^{23}$, Catalase $(\mathrm{CAT}){ }^{24}$ and Glutathione Peroxidase (GP) ${ }^{25}$.

\section{Statistical analysis}

The difference of biochemical parameters were measured using the statistical method i.e. Analysis of Variance (ANOVA). Analysis of Variance refers to the examination of differences among the samples and the results are expressed as mean \pm SEM and $\mathrm{p}<0.05, \mathrm{p}<0.01, \mathrm{p}<0.001$ was considered to be statistically significant.

\section{Results and discussion}

The hepatoprotective and antioxidant activity of S. grandiflora leaves extracts are shown in Figure. 24. the biochemical parameters such as serum glutamate oxaloacetate transaminase, serum glutamate pyruvate transaminase, serum bilirubin and alkaline phosphatase were estimated to assess the liver function. The marked increase in SGOT, SGPT and ALP levels were observed in $\mathrm{CCl}_{4}$ treated group II animals are $94.98 \pm 0.69,29.98 \pm 0.67$ and $299.68 \pm 0.12 \mathrm{IU} / \mathrm{L}$, respectively. The increased level of SGOT, SGPT, ALP and bilirubin is conventional indicator of liver injury. However these levels were reversed to near normal levels of group I animals with treatment of aqueous, ethanol and acetone extract of Sesbania grandiflora, which are statistically significant. The activities of extracts were comparable to a standard drug. These extracts has restored the all the biochemical parameters levels in serum. And also the standard silymarin has restored the biochemical levels of SGOT, SGPT, and ALP significantly $(\mathrm{p}<0.01)$ i.e. 69.42 \pm 0.38 , $24.42 \pm 0.33$, and $170.12 \pm 0.25 \mathrm{IU} / \mathrm{L}$ respectively in serum. In case of bilirubin and total protein there was a noticeable increase i.e. in serum levels treating with $\mathrm{CCl}_{4}$. Treatment with aqueous, ethanol and acetone extract has reversed the serum bilirubin and total protein in serum levels to $(0.50 \pm 0.07$ and $6.85 \pm 0.12$ $\mathrm{mg} / \mathrm{dl}),(0.45 \pm 0.09$ and $6.59 \pm 0.32 \mathrm{mg} / \mathrm{dl}),(0.47 \pm 1.06$ and $6.26 \pm 1.07 \mathrm{mg} / \mathrm{dl})$, respectively which are statistically highly significant $(\mathrm{p}<0.001)$ when compared with $\mathrm{CCl} 4$ treated animals. 
DOI: $10.21522 /$ TIJBMS.2016.02.02.Art001

ISSN: $2519-500 \mathrm{X}$

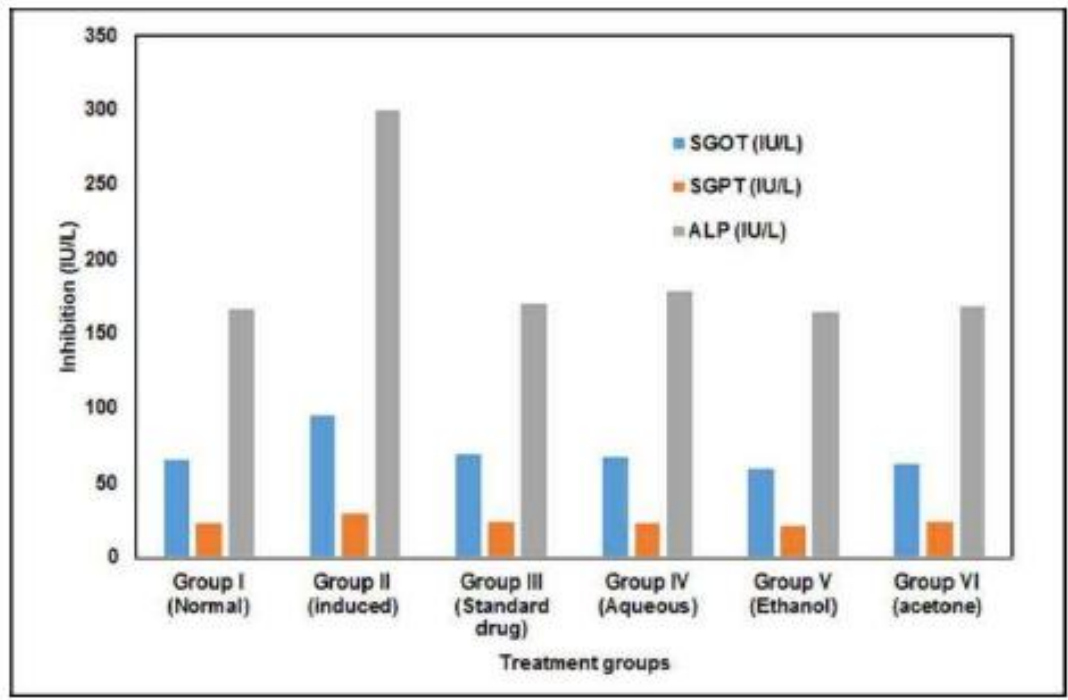

Figure. 2. Hepatoprotective activity in carbon tetra chloride induced hepatotoxic model shows changes serum enzymes sgot, sgpt and alp in serum

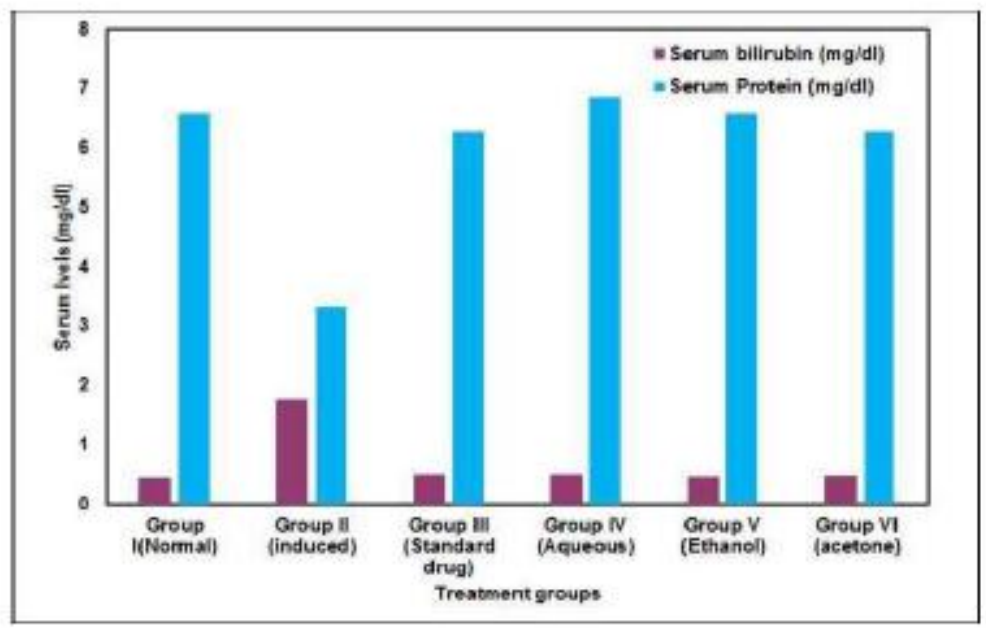

Figure 3. Hepatoprotective activity in carbon tetra chloride induced hepatotoxic model shows changes serum bilirubin and total protein

The restoration of biochemical factors in serum was also noticed in treating with the standard drug silymarin $(0.49 \pm 0.04$ and $6.26 \pm 0.16 \mathrm{mg} / \mathrm{dl})$. It is stipulated that the extract treated group was protected from hepatic cell damage caused by $\mathrm{CCl}_{4}$ induction. The extract at a dose of $300 \mathrm{mg} / \mathrm{kg}$ body wt. exhibited orally, significant protective effect by lowering the serum levels of transaminases (SGOT and SGPT), bilirubin and alkaline phosphatase (ALP).

The effects produced were comparable to that of a standard hepatoprotective agent silymarin. In ethanol extract treated animals, the toxicity effect of carbon tetrachloride was controlled significantly by restoration of the levels of serum bilirubin and enzymes as compared to the normal and standard drug silymarin-treated groups. Antioxidant activities of hepatic SOD, CAT and GPx were estimated and shown in the Table 3, Figure. 4 SOD, CAT and GPx activities were significantly $(\mathrm{p}<0.001)$ enhanced only in the orally received ethanol extract of $S$. grandiflora leaves. The antioxidant activities of aqueous, ethanol and acetone extract shows significant activity near to the normal group of animals. 
Table 1. Hepatoprotective activity in carbon tetra chloride induced hepatotoxic model shows changes serum enzymes sgot, sgpt and alp in serum

\begin{tabular}{llll}
\hline Parameters & SGOT(IU/L) & SGPT(IU/L) & ALP(IU/L) \\
\hline Group I (Normal) & $65.15 \pm 0.14 * * *$ & $23.15 \pm 0.17 * * *$ & $166.15 \pm 0.22 * * *$ \\
Group II (induced) & $94.98 \pm 0.69 *$ & $29.98 \pm 0.67 *$ & $299.68 \pm 0.12 *$ \\
Group III (Standard drug) & $69.42 \pm 0.38^{* *}$ & $24.42 \pm 0.33^{* * *}$ & $170.12 \pm 0.25 * * *$ \\
Group IV (Aqueous) & $67.48 \pm 0.39 * *$ & $23.48 \pm 0.38^{* *}$ & $178.48 \pm 0.28 * * *$ \\
Group V (Ethanol) & $59.59 \pm 0.76^{* * *}$ & $21.59 \pm 0.74 * * *$ & $164.51 \pm 0.17 * * *$ \\
Group VI (acetone) & $62.58 \pm 0.34 * * *$ & $24.58 \pm 0.35^{* *}$ & $168.59 \pm 0.73 * * *$ \\
\hline
\end{tabular}

$* \mathrm{p}<0.05, * * \mathrm{p}<0.01, * * \mathrm{p} p<0.001$ value are considered statistically significant (BMRT)

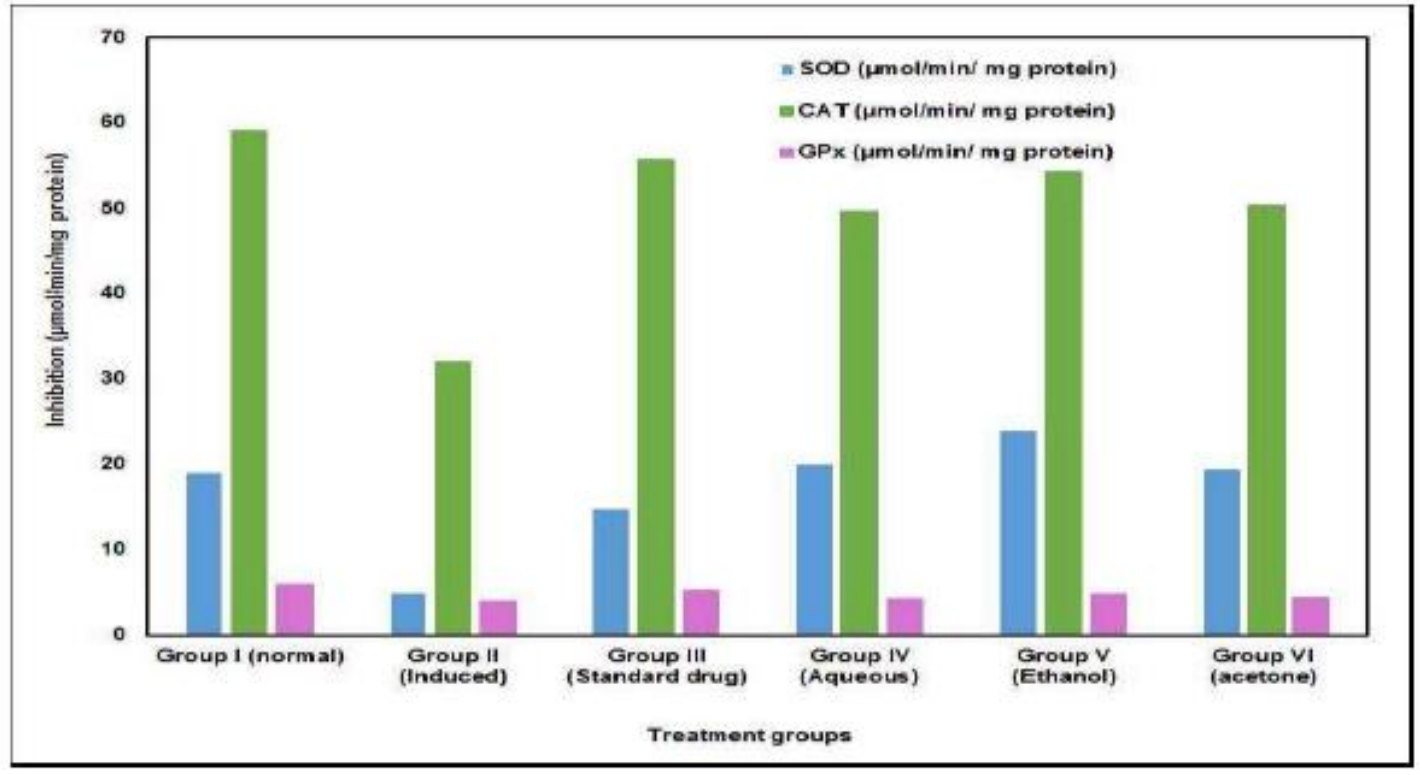

Figure 4. Antioxidant levels in carbon tetra chloride induced hepatotoxic model shows changes in the levels of sod, cat and GPx

Table 2. Hepatoprotective activity in carbon tetra chloride induced hepatotoxic model shows changes serum bilirubin and total protein

\begin{tabular}{lll}
\hline Parameters & $\begin{array}{l}\text { Serum bilirubin } \\
(\mathbf{m g} / \mathbf{d l})\end{array}$ & $\begin{array}{l}\text { Serum Protein } \\
(\mathbf{m g} / \mathbf{d l})\end{array}$ \\
\hline Group I(Normal) & $0.44 \pm 0.03^{* * *}$ & $6.58 \pm 0.06^{* * *}$ \\
Group II(induced) & $1.76 \pm 0.10^{*}$ & $3.32 \pm 0.04^{*}$ \\
Group III(Standard drug) & $0.49 \pm 0.04^{* * *}$ & $6.26 \pm 0.16^{* *}$ \\
Group IV (Aqueous) & $0.50 \pm 0.07^{* *}$ & $6.85 \pm 0.12^{* *}$ \\
Group V (Ethanol) & $0.45 \pm 0.09^{* * *}$ & $6.59 \pm 0.32 * * *$ \\
Group VI (acetone) & $0.47 \pm 1.06^{* *}$ & $6.26 \pm 1.07 * * *$ \\
\hline
\end{tabular}

${ }^{*} \mathrm{p}<0.05, * * \mathrm{p}<0.01, * * * \mathrm{p}<0.001$ value are considered statistically significant (BMRT) 
DOI: $10.21522 /$ TIJBMS.2016.02.02.Art001

ISSN: $2519-500 \mathrm{X}$

Table 3. Antioxidant levels in carbon tetra chloride induced hepatotoxic model Shows changes in the levels of sod, cat and GPX

\begin{tabular}{llll}
\hline Parameters & $\begin{array}{l}\text { SOD }(\boldsymbol{\mu m o l} / \mathbf{m i n} / \\
\mathbf{m g} \mathbf{~ p r o t e i n})\end{array}$ & $\begin{array}{l}\text { CAT }(\boldsymbol{\mu m o l} / \mathbf{m i n} / \\
\mathbf{m g} \text { protein) }\end{array}$ & $\begin{array}{l}\mathbf{G P x} \\
(\boldsymbol{\mu m o l} / \mathbf{m i n} / \\
\mathbf{m g} \mathbf{p r o t e i n})\end{array}$ \\
\hline Group I (Normal) & $18.91 \pm 0.31^{* * *}$ & $58.99 \pm 4.80^{* * *}$ & $5.98 \pm 2.46^{* * *}$ \\
Group II(induced) & $04.94 \pm 0.21^{*}$ & $31.89 \pm 3.43^{*}$ & $3.98 \pm 0.35^{*}$ \\
Group III(Standard drug) & $14.73 \pm 0.39^{* *}$ & $55.67 \pm 3.13^{* *}$ & $5.34 \pm 2.11^{* *}$ \\
Group IV (Aqueous) & $20.01 \pm 0.17^{* *}$ & $49.68 \pm 0.55^{* * *}$ & $4.32 \pm 1.92^{* *}$ \\
Group V (Ethanol) & $23.92 \pm 0.27^{* * *}$ & $54.23 \pm 3.17^{* * *}$ & $4.84 \pm 1.70^{* * *}$ \\
Group VI (acetone) & $19.46 \pm 0.11^{* * *}$ & $50.38 \pm 0.18^{* * *}$ & $4.42 \pm 1.02^{* * *}$ \\
\hline
\end{tabular}

$* \mathrm{p}<0.05, * * \mathrm{p}<0.01, * * * \mathrm{p}<0.001$ value are considered statistically significant (BMRT).

\section{Conclusion}

In the present report stated that the aqueous, ethanol and acetone extract of commonly available plant Sesbania grandiflora leaves was extensively investigated for its hepatoprotective potential against $\mathrm{CCl}_{4}$ induced hepatotoxicity. There was a significant increase in serum levels of bilirubin, alanine transaminase, aspartate transaminase and alkaline phosphatase with a decrease in total protein level, in the $\mathrm{CCl}_{4}$ treated animals, reflecting liver injury. In the extracts treated animals there was a decrease in serum levels of the markers and significant increase in total protein, indicating the recovery of hepatic cells. A strong conclusion can be drawn that, extract of Sesbania grandiflora possess most significant $(\mathrm{p}<0.001)$ hepatoprotective activity compared with the standard drug silymarin. So that the development of medicines using the extracts of plant materials or bioactive compounds with standards of safety and efficacy can revitalize treatment of liver disorders and hepatoprotective activity.

\section{References}

[1].Aneja S, M Vats, S Aggarwal, S Sardana, Phytochemistry and hepatoprotective activity of aqueous extract of Amaranthus tricolor Linn. Roots, Journal of Ayurveda \& Integrative Medicine, 2013, Vol 4, Issue 4, 211-215.

[2].Aebi H., Catalase invitro. Methods in Enzymol, 1984, 105, 121-126.

[3].Bhawna S, S Upendra Kumar, Hepatoprotective activity of some indigenous plants, International Journal of PharmTech Research vol. 1, No.4, pp 1330-1334.

[4].Berhaut, J., 1976. Flore illustrated of Senegal. Tome V Government of Senegal, pp: 505-520.

[5].Duke JA, Handbook of Energy Crops (Unpublished).Purdue University. 1983.

[6].Fernandez-ChecaJc, Hirano T, Tsukamoto H, Kaplowitz N. Mitochondrial Glutanothione depletion in alcoholic liver disease, Alcohol 1993;10;469-475.

[7].Krasaekoopt W. and Kongkarchanatip A, Antimicrobial properties of Thai Traditional Flower Vegetable Extracts, A.U J.T. 9(2): 71 - 74, 2005.

[8].KhinMaMa, NyuntNyunt and Maung tin: The protective effects of Ecliptaalba on carbon tetrachloride Induced Acute Liver Damage. Toxicol. And Applied Pharmacol. 1978; 45:723-728.

[9].Ibrahim M, KZ Uddin and ML Narasu, Hepatoprotective activity of Boswellia serrate extracts: in vitro and in vivo studies. International Journal of Pharmaceutical Applications, 2011, 2(1): 89-98.

[10]. Lin CC, Yen MH, Lo TS, Lin JM. Evaluation of the hepatoprotective and Antioxidant activity of Boehmerianivea var. nivea and B. niveavar. tenacisssima. J Ethnopharmacol 1998; 60: 9-17.

[11]. Manokaran S , Jaswanth A, Sengottuvelu S , Nandhakumar J, Duraisamy R, Karthikeyan D, et al. Hepatoprotective activity of Aervalanata Linn against paracetamol induced hepatotoxicity in rats. Res J Pharm Tech 2008; 1: 398-400.

[12]. Okawa M, Kinjo J, Nohara T, Ono M. DPPH (1, 1-diphenyl-2- picrylhydrazyl) radical scavenging activity of flavonoids obtained from some medicinal plants. Biol Pharm Bull 2001; 24:1202-5. 
[13]. Patel BA, Patel JD, Raval BP. Hepatoprotective activity of Sachharum officinarum against paracetamol induced hepatotoxicity in rats. Int J Pharm Sci Res 2010; 1: 102-8.

[14]. Ram VJ, Goel A (1999) Curr. Med. Chem., 6, 217-254.

[15]. Roy CK, JV Kamath, M Asad, Heaptoprotective acitivity of Psidiumquajava Linn. Leaf extract, Indian Journal of Experimental Biology, 2006, 44: 305-311.

[16]. Sharma SK, Ali M, Gupta J. Evaluation of Indian Herbal Hepatoprotective Drugs. Recent Progress in Medicinal Plants (Phytochemistry and Pharmacology). Vol. 2. Houston: Research Periodicals and Book Publishing House; 2002. p. 253-70.

[17]. Saxena AK, Singh B, Anand KK. Hepatoprotective effects of Ecliptaalba on Subcellular levels in rats. J Ethnopharmacol 1993; 40: 155-161.

[18]. Saraswat B, Visen PK, Patnaik GK, Dhawan BN. Ex vivo and in vivo Investigations of picroliv from picrorhizakurroa in an alcohol in toxication model in rats. J Ethnopharmacol 1999; 66: 263-269.

[19]. Shyam Kumar B, Gnanasekaran D, Jaishree V, Channabasavaraj KP. Hepatoprotective activity of Coccinia indica leaves extract, Int J Pharm Biomed Res., 2010, 1(4), 154-156.

[20]. Sharma PC, Yelre HB and Dennis JJ. Database on medicinal plants used in CCRAS publication, Ayurveda, 2005; $1-6$.

[21]. Schuppan D, Athionson J, Ruehl M, Riecken EO, Alcohol and liver fibrosis-Pathobiochemistry and treatment. Z Gastroenterol, 1995; 33; 546-550.

[22]. Torres-Duran PV, Miranda-Zamora R, Paredes-Carbajal MC, Mascher D, Ble-Castello J, Diaz- Zagoya JC, Juarez-Oropeza MA. Studies on the preventive effect of Spirulina maxima on fatty liver development induced by carbon tetrachloride, in the rat. J Ethnopharmacol 1999; 64: 141-147.

[23]. UkedaH; S Maeda; T Ishii; M Sawamura; Anal. Biochem. 1997, 251, 206-209.

[24]. Vaidhyaratnum PSV. Indian medicinal plants. A compendium of 500 species. Volume V, Orient Longman, Madras, India, 1996; 17 -118.

[25]. Zafar R, Mujahid Ali S. Anti-hepatotoxic effects of root and root callus extracts Of Cichoriumintybus L. J Ethnopharmacol 1998; 63:227-231. 